\title{
ATA DE EXAME DA VILA IRATY (1902)
}

Claudia Maria Petchak Zanlorenzi Bruna Buhler Gomes

O presente documento trata-se de uma ata da escola pública de Iraty, da professora Rosalina Cordeiro de Araújo, hoje atual cidade de Irati, no estado do Paraná. Este livro de registro formal baseava-se no Regulamento Instrucção Pública do Estado do Paraná, decreto $\mathrm{n}^{\circ} 93$ de 11 de março de 1901, que prevê, em seu capítulo X, artigo 56, "Em todas escola públicas do Estado durante o mez de Novembro de cada anno, haverá exames parciaes e finaes, presididos pelos inspectores escolares respectivamente" (PARANÁ, 1901, p. 98)

$\mathrm{Na}$ ata de 24 de novembro de 1902, consta o registro da avaliação realizada por uma comissão presidida pelo inspetor escolar que “[...] procederá, em tudo, de conformidade com o disposto art. 57 e seus números" (PARANÁ, 1901, p. 89) o qual determina ordenadamente como deverá acontecer o exame, concluindo que no caso de aprovação “[...] a comissão examinadora dará aos alumnos, logo após os exames, attestado de habilitação em taes matérias" (PARANÁ, 1901, p. 99). Para presenciar esse exame, marcado previamente, será nomeada uma "[...] comissão examinadora, composta de duas pessoas idôneas, que serão convidadas com a devida antecedência" (PARANÁ, 1901, p. 99). Juntamente com o processo de avaliação, nas escolas para o sexo feminino e promíscuas, conforme artigo $60^{\circ}$ do referido documento, fará parte da comissão julgadora "[...] uma examinadora de trabalhos de agulha e prendas domésticas, para meninas, a qual manifestará seu juízo a respeito das habilitações das examinandas, por occasião do julgamento respectivo" (PARANÁ, 1901, p. 100).

Referências:

IRATI. Ata de exame de vinte e quatro de novembro de 1902. Museu Municipal de Irati.

PARANÁ. Regulamento Instrucção Pública do Estado do Paraná, decreto no 93 de 11 de março de 1901. Arquivo Público do Paraná 


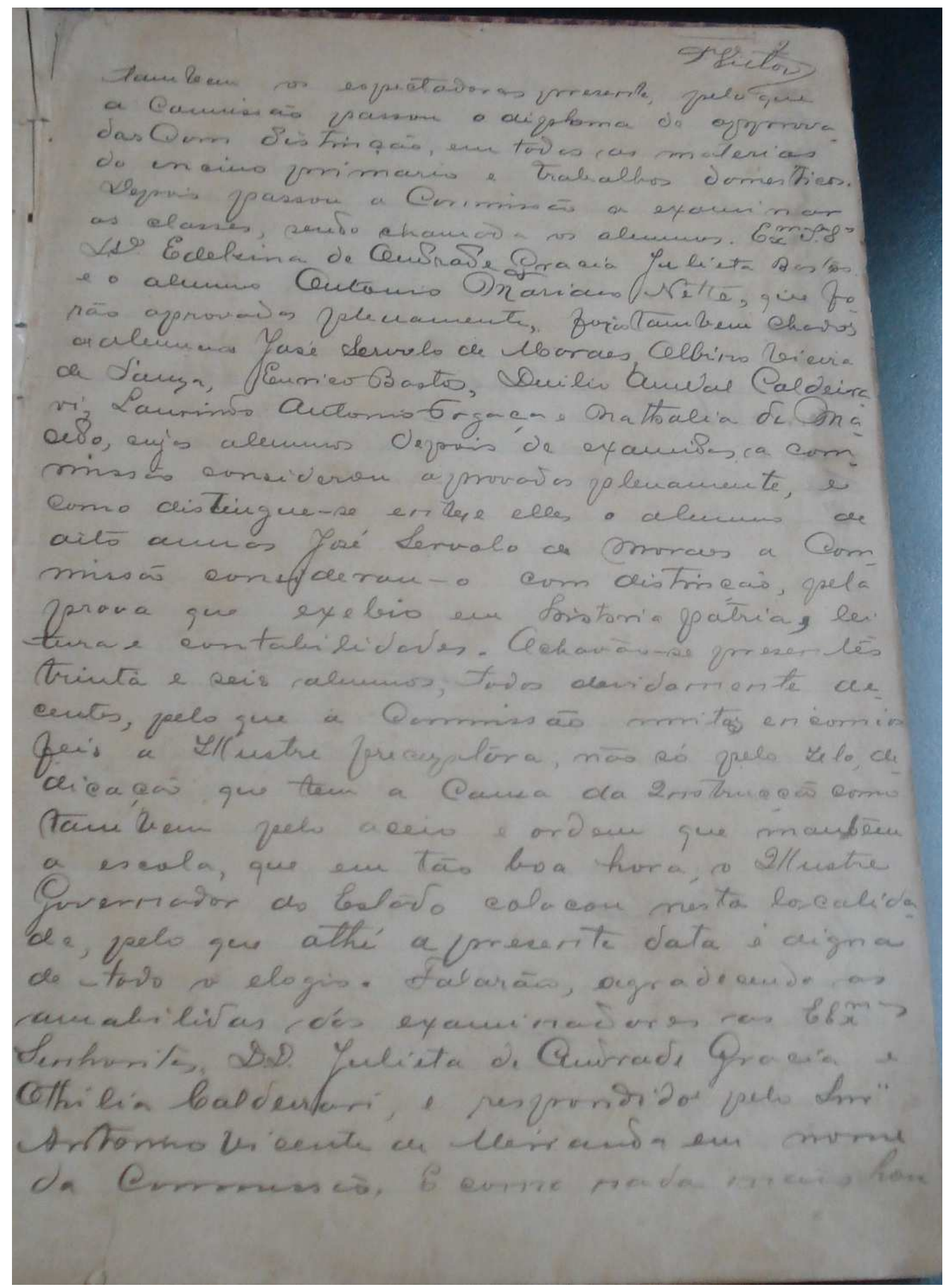




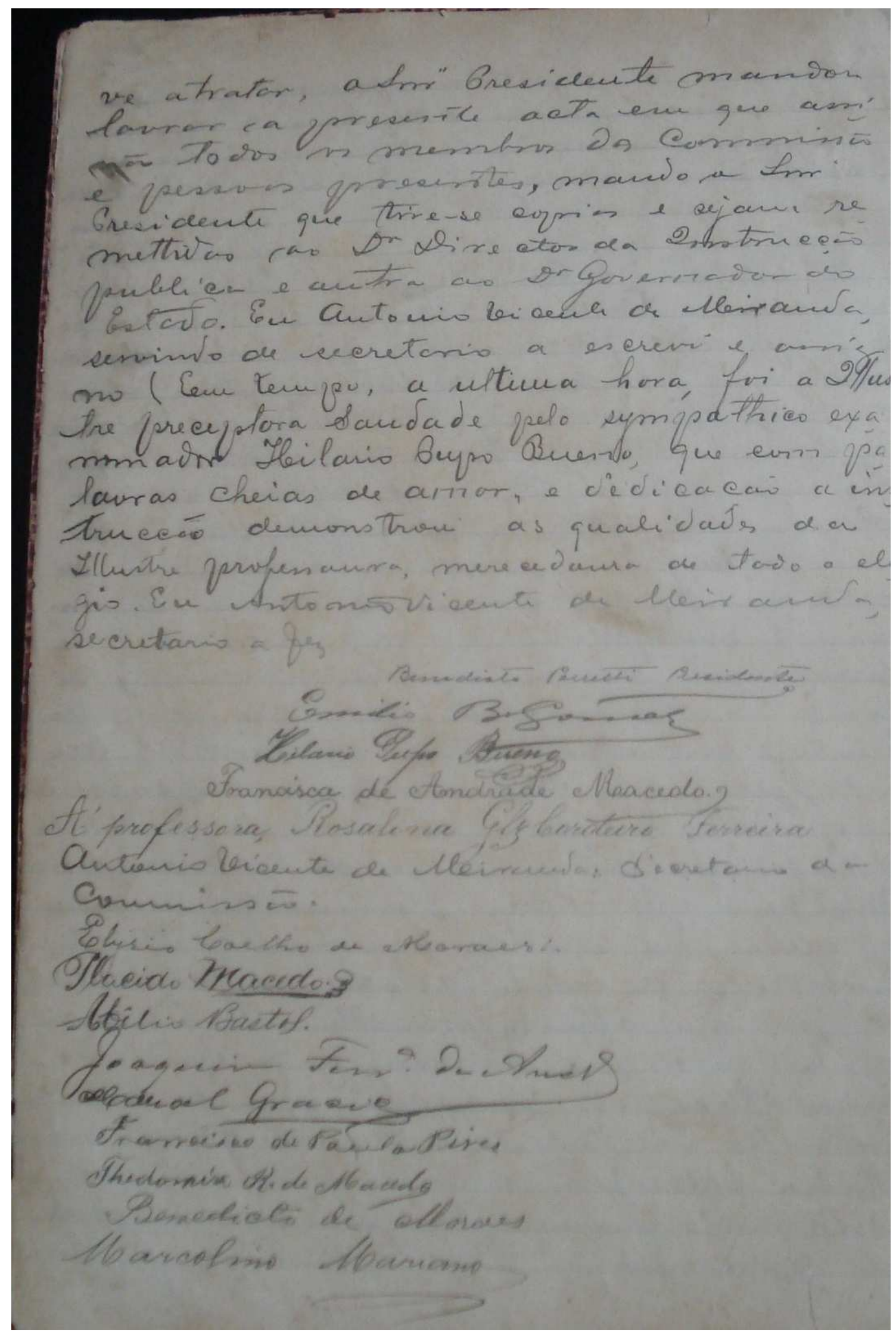

